\title{
A checklist and conservation status of the medicinal plants of Mount Arayat National Park, Pampanga, Philippines
}

\author{
MARLON DL. SUBA ${ }^{1,4, \boldsymbol{v}}$, AXEL H. ARRIOLA ${ }^{1,2}$, GRECEBIO JONATHAN D. ALEJANDRO ${ }^{1,3}$ \\ ${ }^{1}$ The Graduate School, University of Santo Tomas, España, Manila 1015, Philippines. "email: suba.marlon@auf.edu.ph. \\ ${ }^{2}$ Department of Biological Sciences, College of Arts and Sciences, University of the East, 2219 C.M. Recto Ave, Manila, Philippines \\ ${ }^{3}$ College of Science and Research Centre for the Natural \& Applied Sciences, University of Santo Tomas, España, Manila 1015, Philippines \\ ${ }^{4}$ Department of Biological Sciences, College of Arts and Sciences, Angeles University Foundation, Angeles City, Pampanga 2009, Philippines
}

Manuscript received: 4 March 2019. Revision accepted: 18 March 2019.

\begin{abstract}
Suba MDL, Arriola AH, Alejandro GJD. 2019. A checklist and conservation status of the medicinal plants of Mount Arayat National Park, Pampanga, Philippines. Biodiversitas 20: 1034-1041. A checklist of medicinal plants in a natural area is fundamental not only because it provides an updated reference but also it gives the current status of biodiversity. In this study, available medicinal plants in Mt. Arayat National Park (MANP) were documented. Available references on Philippine medicinal plants were used to assess the medicinal values of the MANP flora. To determine the conservation status of the MANP medicinal plants, the assessment of the International Union of Conservation of Nature (IUCN) and a list from the Department of Environment and Natural Resources (DENR) in the Philippines were consulted. A total of 60 medicinal species in 27 families were recorded in MANP. Leguminosae had the highest number of medicinal plants and the genus Ficus had the most species. Based on the literature, most of the plants were used to treat infectious and parasitic diseases and diseases of the digestive system. In terms of the conservation status, six species were vulnerable and five of least concern according to the IUCN listing while one species was listed as vulnerable and the rest of the medicinal plants were marked as not evaluated in the DENR list. This checklist provides data of various medicinal plants to emphasize their uses and need of conservation.
\end{abstract}

Keywords: Diversity, endemicity, herbal medicine, protected area, stratovolcano

\section{INTRODUCTION}

Medicinal plants have been identified and used throughout human history. According to the World Health Organization (WHO, 2011), many people across the world have used herbal medicine to treat various health challenges in different national healthcare settings. Around $80 \%$ of the population use conventional medicine in Africa, Asia and Latin America and many governments in these regions have integrated traditional medicine practices to assist their primary health care services (Payyappallimana 2010). Furthermore, it is estimated that approximately $25 \%$ of modern medicines are derived from herbal products and the annual global export value of pharmaceutical plants in 2011 accounted for over US\$2.2 billion (WHO 2011).

Long before the introduction of modern medicines and western curative methods, herbal medicines were widely used in the Philippines. There are about 1500 medicinal plants from more than 13,500 plant species known in the country (Tan and Sia 2014). This makes the Philippines to be classified by WHO along with Hong Kong, Malaysia, Mongolia, Singapore, Thailand, and Australia, as a country where traditional medicine has remained a vital component of health care system despite of the availability of wellestablished alternatives (Mukherjee 2002; Dela Cruz and Ramos 2006).

In 1997, the National Biodiversity Strategy and Action Plan (NBSAP) identified several areas in the Philippines as centers of biodiversity including the Mt. Arayat National
Park, MANP (DENR/UNEP 1997). This mountain is an isolated and dormant stratovolcano located in the northeastern portion of the province of Pampanga, Luzon which covers an aggregate area of 3,715.28 hectares and with the highest elevation of about 1030 meters (Dagamac et al. 2014). Further, MANP is a protected area by the virtue of Proclamation 203 on September 16, 1933. However, only a few studies about MANP's biodiversity have been published.

The richness and the various native floras in mountain have been used as sources of building materials, food, ornamentals, and medicine. Such practices threaten biodiversity, which is one of the most serious environmental problems the world is facing today. According to the U.S. Agency for International Development (USAID 2014), the estimated biodiversity loss is about 1000 species each year due to uncontrollable legal and illegal human activities. In Southeast Asia, the highest relative rate of deforestation with possibility of losing its original area by 2100 is about $78 \%$ and up to $42 \%$ of its biodiversity has been projected (Sodhi 2010). Thus, the Philippine Biodiversity Conservation Priorities (PBCP) has identified MANP as one of the 43 priority areas in the Philippines for plant conservation (DENR/UNEP 1997). Since plants have always been used as primary source for producing drugs in traditional and alternative systems of medicine in various forms, it is, therefore, essential to assess and document important information of the floral resources which can be used to strengthen policies for 
conservation and protection of the remaining biodiversity (Kala et al. 2006). Hence, this study aims to provide a checklist and the current conservation status of medicinal plants of MANP, Pampanga, Philippines.

\section{MATERIAL AND METHODS}

\section{Research ethics}

Research ethics was observed by presenting a letter of request and research proposal to the regional office of the DENR at San Fernando City, Pampanga, Philippines to grant a gratuitous permit. Prior informed consent from the leader of the community who lives in the area was also obtained. The Provincial Environment and Natural Resources Officer (PENRO) of Pampanga provided trained Forest Guides for assistance. Since the nature of the research is participatory, the forest guides were compensated and involved during the entire duration of fieldwork.

\section{Location of study sites}

MANP (15 $12^{\prime} 00^{\prime \prime} \mathrm{N} / 120^{\circ} 43^{\prime}$ 59" $^{\prime \prime}$ E) is a solitary mountain in the central plain of Luzon with elevation ranges from 100-1030 masl. The topography of the park is rolling to moderately steep in the lower parts and generally steep and rugged in the upper portion. A circular volcanic crater about $1.2 \mathrm{~km}$ in diameter covers the western part and a portion of the northern rim has collapsed due to soil erosion (Dagamac et al. 2014). The mountain consists of three peaks; the North peak $\left(15^{\circ} 12^{\prime} 00^{\prime \prime} \mathrm{N} / 120^{\circ} 44^{\prime} 00^{\prime \prime} \mathrm{E}\right)$ is where the main summit occurs with highest elevation of about 1030 meters via Barangay Ayala, Magalang route,

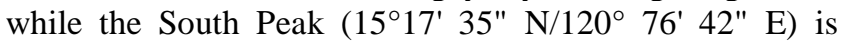
about 984 meters via Barangay San Juan Banyo, Arayat route and the Pinnacle Peak ( $\left.15^{\circ} 10^{\prime} 60^{\prime \prime} \mathrm{N} / 120^{\circ} 43^{\prime} 59^{\prime \prime} \mathrm{E}\right)$ is about 786 masl, situated between the north and the south peaks. Since the Pinnacle Peak trails are quite dangerous due to its ridgeline, only the North and South Peaks were allowed to be studied. The MANP has an annual temperature range of $22-31^{\circ} \mathrm{C}$ which falls under the Climatic Type I with an annual rainfall range of 284-1844 $\mathrm{mm}$ (Dagamac et al. 2012). It is characterized by two pronounced seasons: dry from November to April and wet from May to October.

\section{Plant collections}

Since MANP exhibits two pronounced seasons, the floristic surveys were done in the North and South Peaks (Figure 1) during wet season, September 2016 and dry season, April 2017. According to Rathcke and Lacey (2003), there are correlations between seasonal changes in the physical environment and the simultaneous germination of many species within plant communities. Collected plants were pressed, poisoned and mounted as herbarium vouchers. Herbarium specimens were labeled and kept at the University of Santo Tomas Herbarium (USTH), Philippines. All field data gathered were documented in the field notebook and photographs of the different morphological features were used as an aid in the succeeding process of identification.

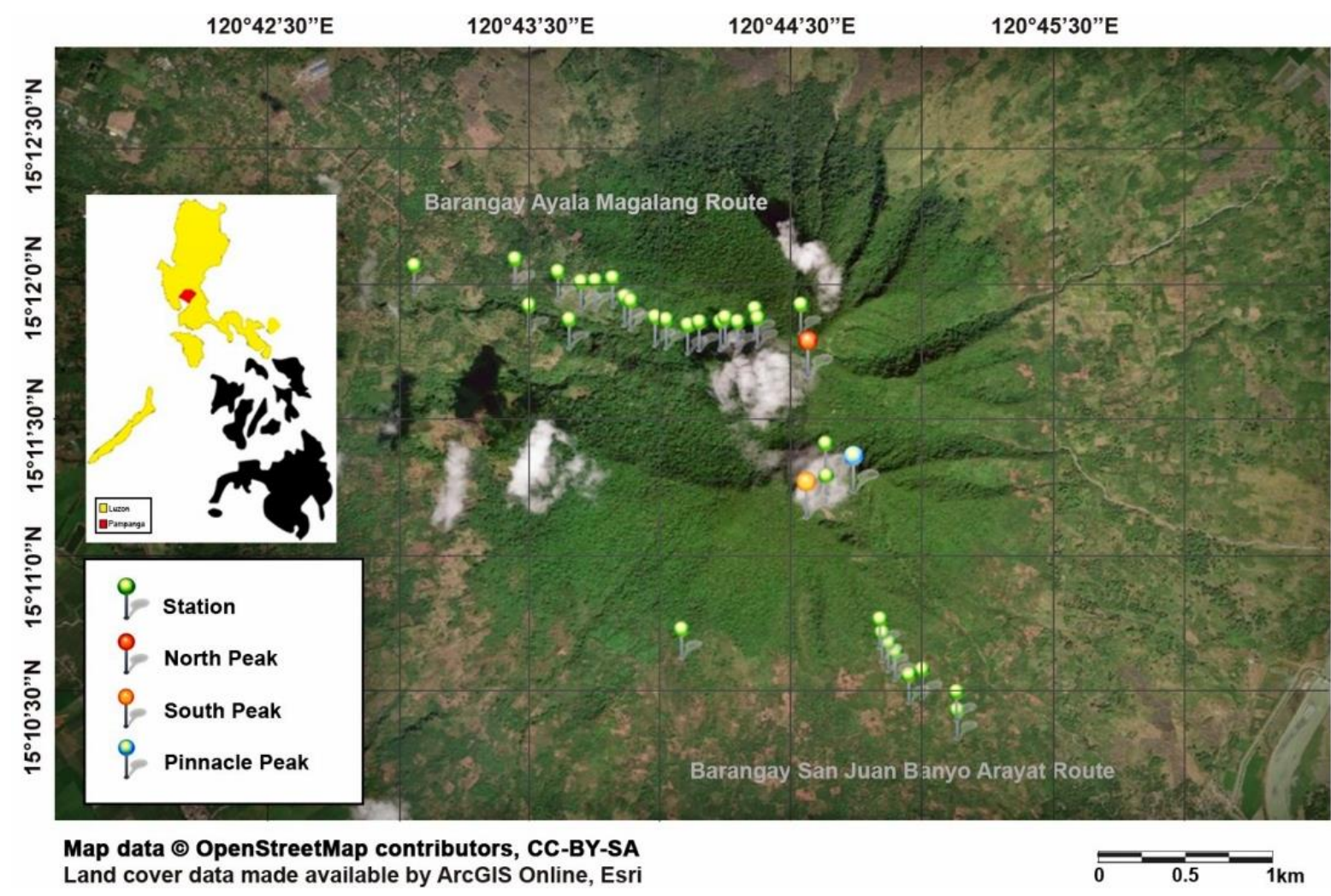

Figure 1. Map of the study sites in Mt. Arayat National Park. Areas surveyed are marked green for north and south peaks 


\section{Identification of plants}

Identification of the collected specimens was conducted at USTH using literature sources such as de Padua et al. (1999), Madulid (2001), van Valkenburg and Bunyapraphatsara (2002), Keller (2004), Rummel (2005), and Pancho and Gruezo (2006) and some open access websites such as; Pelser et al. (2011-onwards), or type specimens from JSTOR (2000-onwards) and the Global Biodiversity Information Facility (1999-onwards). To validate the scientific names; The Plant List (2010onwards) and Tropicos (2018) online sources were used. While the authentication of unfamiliar plant taxon was identified by the curator at USTH.

\section{Determination of medicinal values, conservation status, and endemicity}

To determine the medicinal values of the collected specimens, published books by de Tavera and Hermenegildo (1892), Quisumbing (1951), and Tan (1980) were reviewed. These published books include extensive entries for medicinal plants of the Philippines and accessibility in institution libraries and online sources (Carag and Buot 2017). Websites such as Philippine Alternative Medicine (2011-onwards) and Philippine Traditional Knowledge Digital Library on Health (20152016) were also utilized. These websites contain updated compilation mostly of ethnobotanical and ethnopharmacological researches in the Philippines that are published from reputable journals.

To determine the conservation status for each species, whether Critically Endangered (CR), Endangered (EN), Vulnerable (VU), and Least Concern (LC), the International Union of Conservation of Nature (IUCN) Red List of Threatened Species (2018) and the Department of Environment and Natural Resources (DENR) Administrative Order No. (DAO) 2017-01 (2017) aided in categorizing each species. While Pelser et al. (2011onwards) were used to identify endemic plants.

\section{RESULTS AND DISCUSSION}

\section{Identification}

A total of 60 plant species from 98 collected species (32 trees, 16 shrubs, 1 vine, 1 epiphyte, and 10 herbs) from 27 families were recorded and found to have medicinal values based on available literature (Table 1). This represents $4.35 \%$ of 620 plant families of the world (The Plant List, 2010-onwards). Leguminosae (9 species), followed by Moraceae (6 species), Euphorbiaceae and Lamiaceae (5 species each), and Asteraceae (4 species) were the most diverse. Further, Apocynaceae, Araceae, and Malvaceae were represented by three species each, while Amaranthaceae, Meliaceae, and Rutaceae were represented by two species each. The remaining 16 families were represented by a single species. On the other hand, Ficus was the most species-rich genus with three species recorded; Ficus nota (Blanco.) Merr., Ficus ulmifolia Lam., and Ficus septica Burm.f., followed by Artocarpus J.R. Forst. \& G.Forst. and Macaranga Thouars with two species each (Table 2).

Since taxonomic names change frequently, some older names or synonyms of these plants were encountered. These synonyms are still valid as provided by the International Code of Nomenclature for algae, fungi, and plants (ICN). The plants listed in Quisumbing (1951); Epipremnum merrillii Engl. \& K.Krause, Callicarpa cana L., and Kolowratia elegans Presl. are synonyms of Epipremnum pinnatum (L.) Engl., Callicarpa candicans (Burm.f.) Hochr. and Alpinia elegans (C.Presl) K.Schum. respectively. While in the list of de Tavera and Hermenegildo (1892), the Pongamia glabra Vent. is found as a synonym of Pongamia pinnata (L.) Pierre.

\section{Medicinal values}

Based on the review and consolidation of medicinal data, the Alstonia scholaris (L.) R.Br., Tectona grandis L.f., Caesalpinia pulcherrima (L.) Sw., Gliricidia sepium (Jacq.) Kunth ex. Steud, Leucaena leucocephala (Lam.) de Wit, Tamarindus indica L., Sida acuta Burm. f., Melastoma malabathricum L., and Sandoricum koetjape (Burm.f.) Merr. were listed in all the references consulted (de Tavera, and Hermenegildo 1892; Quisumbing 1951; Tan 1980) and in online sources. Meanwhile, medicinal data for Wrightia pubescens R.Br., Cosmos sulphureus Cav., Reutealis trisperma (Blanco) Airy Shaw, Albizia lebbeck (L.) Benth., Swietenia macrophylla King, and Leea guineensis G. Don were only found in the Philippine Alternative Medicine (2011-onwards). Nevertheless, much of the knowledge from the various references consulted refer to medicinal uses that are also maintained and developed by all indigenous groups in the Philippines. This knowledge is inherited way back from their great ancestors through verbal communication (Olowa et al. 2012).

The majority of the documented plants in MANP had many medicinal uses to treat certain illnesses and diseases. For example, Lagerstroemia speciosa (L.) Pers. locally known as banaba has long been known both locally and abroad for its diuretic and hypoglycemic properties (Tan 1980). It is important to mention that some authors like Quisumbing (1951) listed this plant for treatment of other diseases as well, such as abdominal pain, diarrhea, and it has been used as an astringent.

Table 1. Taxonomic inventory of medicinal plants in Mt. Arayat National Park.

\begin{tabular}{lccc}
\hline \multirow{2}{*}{ Plant groups } & \multicolumn{3}{c}{ Total number of } \\
\cline { 2 - 4 } & Families & Genera & Species \\
\hline Trees & 14 & 28 & 32 \\
Shrubs & 12 & 15 & 16 \\
Herbs & 6 & 10 & 10 \\
Vines & 1 & 1 & 1 \\
Epiphytes & 1 & 1 & 1 \\
& & Total & 60 \\
\hline
\end{tabular}


Table 2. List of 60 medicinal plant species identified in Mt. Arayat National Park, Philippines

\begin{tabular}{|c|c|c|c|c|c|c|}
\hline Family & Species & Habit & Status & $\begin{array}{c}\text { Endemi } \\
\text { city }\end{array}$ & Medicinal value & $\begin{array}{l}\text { Medicinal } \\
\text { reference }\end{array}$ \\
\hline \multicolumn{7}{|c|}{ Amaranthaceae } \\
\hline & Achyranthes aspera $\mathrm{L}$. & $\mathrm{H}$ & NE & $\mathrm{N}$ & Urinary diseases & $1,2,3,5$ \\
\hline & Cyathula prostata (L.) Blume & $\mathrm{H}$ & NE & $\mathrm{N}$ & Scabies, dysentery & 1,3 \\
\hline \multicolumn{7}{|c|}{ Anacardiaceae } \\
\hline & Semecarpus cuneiformis Blanco & $\mathrm{T}$ & NE & $\mathrm{N}$ & Indolent ulcers, chicken pox & $1,2,3$ \\
\hline \multicolumn{7}{|c|}{ Anonaceae } \\
\hline & Anaxagorea luzonensis A.Gray & $\mathrm{S}$ & $\mathrm{NE}$ & $\mathrm{N}$ & Stomachache, rheumatism & $1,2,3$ \\
\hline \multicolumn{7}{|c|}{ Apocynaceae } \\
\hline & Alstonia scholaris (L.) R. Br. & $\mathrm{T}$ & $\mathrm{LC}$ & $\mathrm{N}$ & Fever, chronic diarrhea, dysentery & 6 \\
\hline & Parameria laevigata (Juss.) Moldenke & S & NE & $\mathrm{N}$ & Wounds & 1,2 \\
\hline & Wrightia pubescens $\mathrm{R} . \mathrm{Br}$. & $\mathrm{T}$ & NE & $\mathrm{N}$ & Dysentery, arthritis & 1 \\
\hline \multicolumn{7}{|l|}{ Araceae } \\
\hline & Alocasia macrorrhizos (L.) G. Don. & $\mathrm{H}$ & NE & $\mathrm{N}$ & Joint pains, fevers & $1,2,3$ \\
\hline & Epipremnum pinnatum (L.) Engl. & $\mathrm{E}$ & NE & $\mathrm{N}$ & Snake bites & $1,2,3$ \\
\hline & Pothos cylindricus C. Presl & $\mathrm{H}$ & $\mathrm{NE}$ & $\mathrm{N}$ & Stuck fishbone & 2 \\
\hline \multicolumn{7}{|c|}{ Araliaceae } \\
\hline & Schefflera odorata (Blanco) Merr. \& Rolfe & S & NE & $\mathrm{N}$ & Wounds, arthritis, rheumatism & $1,2,3$ \\
\hline \multicolumn{7}{|c|}{ Asteraceae } \\
\hline & $\begin{array}{l}\text { Chromolaena odorata (L.) R.M.King \& } \\
\text { H.Rob }\end{array}$ & $\mathrm{S}$ & $\mathrm{NE}$ & $\mathrm{N}$ & Wounds, fever & 1,2 \\
\hline & Cosmos sulphureus Cav & $\mathrm{H}$ & NE & $\mathrm{N}$ & Malaria & 1 \\
\hline & Mikania cordata (Burm.f.) B.L. Rob. & $\mathrm{H}$ & NE & $\mathrm{N}$ & Wound, diarrhea, stomach infection & $1,2,3$ \\
\hline & Pseudelephantopus spicatus (B.Juss. ex & $\mathrm{H}$ & NE & $\mathrm{N}$ & Eczema & $1,2,3$ \\
\hline & Aubl.) Rohr ex C.F.Baker & & & & & \\
\hline \multicolumn{7}{|c|}{ Burseraceae } \\
\hline \multirow{2}{*}{\multicolumn{7}{|c|}{ Chloranthaceae }} \\
\hline & & & & & & \\
\hline & Sarcandra glabra (Thunb.) Nakai & $\mathrm{S}$ & NE & $\mathrm{N}$ & Kidney diseases & 1,3 \\
\hline \multicolumn{7}{|c|}{ Dioscoreaceae } \\
\hline & Tacca palmata Blume & $\mathrm{H}$ & NE & $\mathrm{N}$ & Diarrhea, dysentery & 1,2 \\
\hline \multicolumn{7}{|c|}{ Euphorbiaceae } \\
\hline & Reutealis trisperma (Blanco) Airy Shaw & $\mathrm{T}$ & VU & $\mathrm{N}$ & Purgative, dandruff & 1 \\
\hline & Macaranga grandifolia (Blanco.) Merr. & $\mathrm{T}$ & VU & $\mathrm{E}$ & Mouth ulcers & 1,3 \\
\hline & Macaranga tanarius (L.) Müll.Arg. & $\mathrm{T}$ & $\mathrm{NE}$ & $\mathrm{N}$ & Hemoptysis, fever, cough & $1,2,3$ \\
\hline & Manihot esculenta Crantz & $\mathrm{S}$ & NE & $\mathrm{N}$ & Skin diseases & $1,2,3$ \\
\hline & Melanolepis multiglandulosa (Reinw. ex & $\mathrm{T}$ & $\mathrm{NE}$ & $\mathrm{N}$ & Skin diseases & $1,2,3$ \\
\hline \multicolumn{7}{|c|}{ Lamiaceae } \\
\hline & Callicarpa candicans (Burm.f.) Hochr. & $\mathrm{S}$ & NE & $\mathrm{N}$ & Asthma, gastralgia, fever & $1,2,3$ \\
\hline & Gmelina arborea Roxb. & $\mathrm{T}$ & NE & $\mathrm{N}$ & Arthritis, sprain & 1,2 \\
\hline & Hyptis suaveolens (L.) Poit. & $\mathrm{S}$ & $\mathrm{NE}$ & $\mathrm{N}$ & Rheumatism, spasm, skin wash & $1,2,3,4$ \\
\hline & Premna odorata Blanco & $\mathrm{T}$ & $\mathrm{NE}$ & $\mathrm{N}$ & Respiratory diseases, headache & $1,2,3,4$ \\
\hline & Tectona grandis L.f. & $\mathrm{T}$ & $\mathrm{NE}$ & $\mathrm{N}$ & $\begin{array}{l}\text { Dermatitis, menstrual disorders, } \\
\text { hemorrhages }\end{array}$ & 6 \\
\hline \multicolumn{7}{|c|}{ 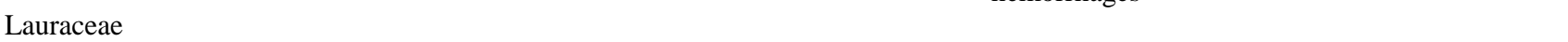 } \\
\hline & Litsea glutinosa (Lour.) C.B. Rob. & $\mathrm{T}$ & NE & $\mathrm{N}$ & Sprains, bruises, rheumatism & $1,2,3$ \\
\hline \multicolumn{7}{|c|}{ Leguminosae } \\
\hline & Albizia lebbeck (L.) Benth. & $\mathrm{T}$ & NE & $\mathrm{N}$ & Diarrhea, dysentery, hemorrhoids & 1 \\
\hline & Bauhinia integrifolia Roxb & $S$ & NE & $\mathrm{N}$ & Bloody sputum, snake bite & 2 \\
\hline & Caesalpinia pulcherrima (L.) Sw. & $\mathrm{S}$ & NE & $\mathrm{N}$ & Tonic, stimulant, intestinal parasite & 6 \\
\hline & Leucaena leucocephala (Lam.) de Wit & $\mathrm{T}$ & NE & $\mathrm{N}$ & $\begin{array}{l}\text { Diabetes, menstrual disorders, } \\
\text { dewormer }\end{array}$ & 6 \\
\hline & Parkia timoriana (DC.) Merr. & $\mathrm{T}$ & NE & $\mathrm{N}$ & $\begin{array}{l}\text { Hepatalgia, edema, nephritis, } \\
\text { diabetes, colic }\end{array}$ & 3 \\
\hline & Pongamia pinnata (L.) Pierre & $\mathrm{T}$ & $\mathrm{LC}$ & $\mathrm{N}$ & Cough, skin diseases, rheumatism & $1,4,5$ \\
\hline & Pterocarpus indicus Willd. & $\mathrm{T}$ & VU & $\mathrm{N}$ & Stomachache & $1,2,5$ \\
\hline & Tamarindus indica $\mathrm{L}$. & $\mathrm{T}$ & $\mathrm{LC}$ & $\mathrm{N}$ & Rheumatism, respiratory diseases & 6 \\
\hline \multicolumn{7}{|c|}{ Lythraceae } \\
\hline & Lagerstroemia speciosa (L.) Pers. & $\mathrm{T}$ & $\mathrm{NE}$ & $\mathrm{N}$ & Diabetes & $1,2,3,4$ \\
\hline \multirow[t]{4}{*}{ Malvaceae } & & & & & & \\
\hline & Kleinhovia hospita $\mathrm{L}$. & $\mathrm{T}$ & NE & $\mathrm{N}$ & Cough, asthma, stimulant & $1,2,5$ \\
\hline & Sida acuta Burm. f. & S & $\mathrm{NE}$ & $\mathrm{N}$ & Fever, stomach ache, rheumatism & 6 \\
\hline & Triumfetta rhomboidea Jacq. & $\mathrm{S}$ & NE & $\mathrm{N}$ & Boil, diarrhea, ulcers & 1,2 \\
\hline
\end{tabular}




\begin{tabular}{|c|c|c|c|c|c|c|}
\hline \multicolumn{7}{|c|}{ Melastomataceae } \\
\hline & Melastoma malabathricum $\mathrm{L}$. & $S$ & NE & $\mathrm{N}$ & Diarrhea, puerperal infections & 6 \\
\hline Meliaceae & & & & & & \\
\hline & Sandoricum koetjape (Burm.f.) Merr. & $\mathrm{T}$ & $\mathrm{LC}$ & $\mathrm{N}$ & Fever, astringent, diarrhea & 6 \\
\hline & Swietenia macrophylla King & $\mathrm{T}$ & VU & $\mathrm{N}$ & Antipyretic, tonic, astringent & 1 \\
\hline \multicolumn{7}{|l|}{ Moraceae } \\
\hline & Artocarpus blancoi (Elmer) Merr. & $\mathrm{T}$ & VU & $\mathrm{E}$ & Heart problem, hernia, diarrhea, & $2,3,4$ \\
\hline & Artocarpus heterophyllus Lam. & $\mathrm{T}$ & NE & $\mathrm{N}$ & Wounds, ulcers & 3 \\
\hline & Ficus nota (Blanco.) Merr. & $\mathrm{T}$ & NE & $\mathrm{N}$ & $\begin{array}{l}\text { Fever, muscle pain, urinary tract } \\
\text { infections, hypertension, diabetes }\end{array}$ & 1,2 \\
\hline & Ficus ulmifolia Lam. & $\mathrm{T}$ & VU & $\mathrm{E}$ & Cold, dewormer & 2,4 \\
\hline & Ficus septica Burm.f. & $\mathrm{T}$ & NE & $\mathrm{N}$ & Headache & 1,2 \\
\hline & Streblus asper Lour. & $\mathrm{T}$ & NE & $\mathrm{N}$ & Skin diseases & $1,2,3$ \\
\hline \multicolumn{7}{|c|}{ Pandanaceae } \\
\hline & Pandanus exaltatus Blanco & $\mathrm{T}$ & NE & $\mathrm{E}$ & Urinary diseases & $1,3,4$ \\
\hline \multicolumn{7}{|c|}{ Passifloraceae } \\
\hline Phyllantha & $\begin{array}{l}\text { Passiflora foetida } \mathrm{L} . \\
\text { ceae }\end{array}$ & V & $\mathrm{NE}$ & $\mathrm{N}$ & Antihelmintic & $1,2,3$ \\
\hline Phyllanthaceae & Antidesma bunius (L.) Spreng & $\mathrm{T}$ & $\mathrm{NE}$ & $\mathrm{N}$ & Diabetes mellitus, diaphoretic & 1,3 \\
\hline \multicolumn{7}{|c|}{ 月лй } \\
\hline & Paspalum conjugatum P.J. Bergius & $\mathrm{H}$ & $\mathrm{LC}$ & $\mathrm{N}$ & Diarrhea & 1,3 \\
\hline Kutaceae & Lunasia amara Blanco & $\mathrm{T}$ & NE & $\mathrm{N}$ & Stomachache, snake bite & $1,2,3,4$ \\
\hline & Micromelum compressum (Blanco) Merr. & $\mathrm{T}$ & $\mathrm{NE}$ & $\mathrm{E}$ & Infantile convulsions & 1,3 \\
\hline \multicolumn{7}{|c|}{ Verbenaceae } \\
\hline Vitaceae & Lantana camara $\mathrm{L}$. & S & $\mathrm{NE}$ & $\mathrm{N}$ & Skin diseases & $1,2,3,4$ \\
\hline Vitaceae & Leea guineensis G. Don & $\mathrm{S}$ & $\mathrm{NE}$ & $\mathrm{N}$ & Wound & 1 \\
\hline \multicolumn{7}{|c|}{ Zingiberaceae } \\
\hline & Alpinia elegans (C.Presl) K.Schum. & $\mathrm{H}$ & $* \mathrm{VU}$ & $\mathrm{E}$ & $\begin{array}{l}\text { Urticaria, arthritis, diarrhea, } \\
\text { stomachache }\end{array}$ & $1,2,3$ \\
\hline
\end{tabular}

Using the categories of the International Classification of Diseases (ICD-11) by the WHO (2018), most of the recorded plant species (33 spp.) were used for certain infectious and parasitic diseases followed by diseases of the digestive system (30 spp.) (Figure 2). Categories such as diseases of the blood or blood-forming organs, diseases of the immune system and diseases of the visual system were treated by only one plant species each. According to the National Economic and Development Authority (NEDA), about $60 \%$ of the Filipino people live below the poverty line and the food and water resources are limited (NEDA 2004). As a result, Filipino masses have learned to rely on their indigenous supplies. These common diseases are believed to be caused by these resources (Carag and Buot 2017).

\section{Conservation status and endemicity}

Out of the 60 medicinal plant species found in MANP, only 12 had been evaluated for their conservation status (Table 3). Based on IUCN List of Threatened Species (2018), six species were identified as vulnerable (VU); $R$. trisperma, Pterocarpus indicus Willd., Macaranga grandifolia (Blanco) Merr., S. macrophylla, Artocarpus blancoi (Elmer) Merr., and F. ulmifolia. Moreover, five species were identified as Least Concern (LC); $A$. scholaris, $P$. pinnata, $T$. indica, S. koetjape, and Paspalum conjugatum P.J. Bergius. While in DENR (2017), only A. elegans was in the list as VU and the rest of the plant species were marked as not evaluated (NE) (Table 3). As ascertained during this study, IUCN and DENR have totally different categories for a selected species and this can be because of their variations in scope or level of assessment (Villanueva and Buot 2015).

Table 3. Summary of threatened and least concern medicinal plant species found in Mt. Arayat National Park, Philippines

\begin{tabular}{lccc}
\hline \multicolumn{1}{c}{ Categories } & IUCN & DENR & Total \\
\hline Critically Endangered (CR) & 0 & 0 & 0 \\
Endangered (EN) & 0 & 0 & 0 \\
Vulnerable (VU) & 6 & 1 & 7 \\
Least Concern (LC) & 5 & 0 & 5 \\
Total (CR, EN, VU, LC) & & & 12 \\
\hline
\end{tabular}




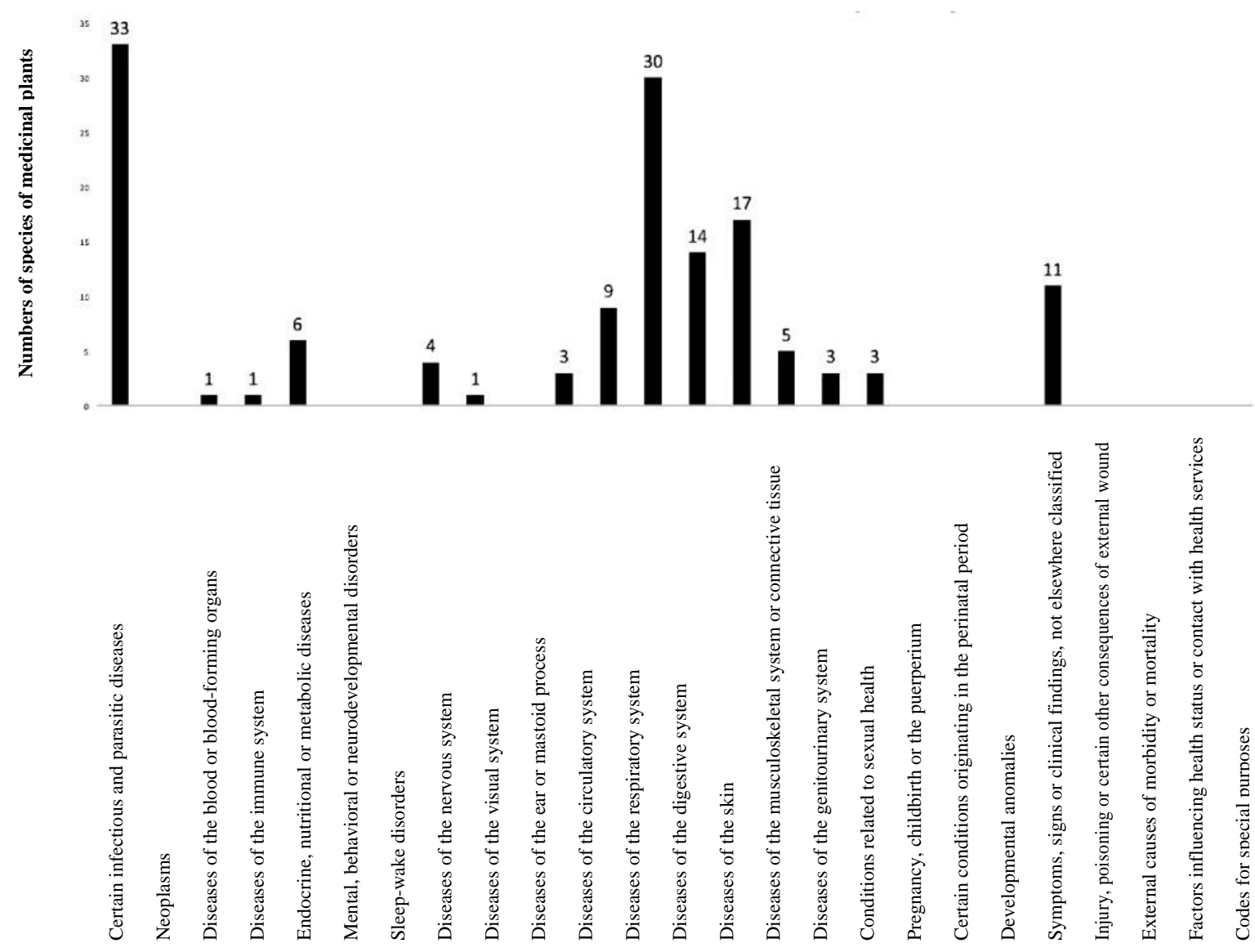

Figure 2. Numbers of species of medicinal plants in Mt. Arayat National Park recorded in each of the categories of International Classification of Diseases (WHO 2018)

In this study, four species assessed as vulnerable are all endemic in the Philippines; A. elegans, M. grandifolia, A. blancoi, and F. ulmifolia (Pelser et al. 2011-onwards). According to Haq et al. (2010), endemic and rare taxa of an area are the most vulnerable because of restricted geographic ranges and specialized habitats. While other restricted plants in the country such as Pandanus exaltatus Blanco, and Micromelum compressum (Blanco) Merr. were neither on the list of IUCN and DENR as threatened species.

As described by the International Union for the Conservation of Nature and Natural Resources (19941997), national parks are relatively large natural areas activity, where extractive resource uses are not allowed, and which are established to protect outstanding natural areas of national or international significance for scientific, educational, and recreational use. However, like any other protected areas, several threats to medicinal plant species are comparable to those causing endangerment to plant diversity in general (Hamilton 2004). In fact, different threats to biodiversity in MANP were observed during the course of the study. Noteworthy threats are charcoal making along the slopes of the mountain specifically in South Peak. Charcoal making utilizes slash and burn techniques that reduce plant cover. Moreover, the expansion of agricultural lands was mostly seen in the
South Peak. Other threats to the park is due to the increase of visitors and the lack of discipline of tourists that trespass the prohibited zones of the mountain because of limited personnel overseeing the area. In MANP, the forest rangers also serve as forest guides and they are also the ones collecting litter left by tourists and mountaineers. It is a common scenario in the Philippines that only few forest rangers are assigned to guard large protected areas (Carag and Buot 2017). The lack of manpower is due to insufficient funding that most of the park area managers are facing which result in poor implementation of conservation laws and measure (Bagadion and Juan 2013).

To date, several projects have been launched to rehabilitate and conserve resources of MANP. The Community Based Program (CBP) is DENR Administrative Order No. 2004-32 which gives opportunities to organize tenured migrant communities and indigenous people to manage, develop, utilize, conserve and protect the resources within the zones of the protected area and buffer zones consistent with the Protected Area Management Plan (PAMP). The Treepreneur Project of Society for the conservation of Philippine wetlands project brought in participation of women and children in tree planting activities and maintenance of the assigned plantation areas at MANP were made (SCPW 2012). Finally, a new eco-tourist destination will soon rise in 
Central Luzon, the 10-hectare San Juan Baño recreational facility at the foot of the fabled MANP will undergo major renovation and rehabilitation under a public-private sector partnership scheme proposed by the local government of Arayat (DENR, 2018).

In conclusion, the present study provided a checklist and conservation status of medicinal plants of MANP, Pampanga, Philippines. The conclusions are: (i) 60 plant species from 27 families were documented, there are seven vulnerable, five least concern species and the rest are not evaluated; and (ii) different threats to biodiversity in MANP were also observed during our field work. The lack of discipline and irresponsible camping practices of visitors, limited manpower, and other human activities such as charcoal making, farm expansion and slash and burn of plants. Though there were only a few documented plant species under threat it cannot be denied that biological diversity is rapidly fading in forest, upland, and even in coastal environments in the Philippines and throughout the world. Several management options can be done such as independent conservation assessment of medicinal plants of MANP which can be used to create distribution map to monitor threatened species. The ex situ conservation for severe cases to improve their population number is also recommended. The result of the study must be addressed to the present management, local community, and government agencies to intensify management program on utilization and conservation of plant diversity in MANP.

\section{ACKNOWLEDGEMENTS}

We thank the Research Center for Natural and Applied Sciences, UST, for the herbarium facility. The present work is part of the graduate thesis of the first author in which financial grant has been obtained from the Commission on Higher Education-Faculty Development Program (CHED-FacDev) for the scholarship and research grant.

\section{REFERENCES}

Bagadion BC, Juan NDD. 2013. Transforming protected areas into effective and sustainable ecotourism destinations: lessons from the ground. Asian Institute of Management, Philippines. Working Paper 13-24, Manila.

Carag H, Buot I Jr. 2017. A checklist of the orders and families of medicinal plants in the Philippines. Sylvatrop 27: 49-59.

Dagamac NH, Stephenson S, dela Cruz TE. 2012.Occurrence, distribution, and diversity of myxomycetes (plasmodial slime molds) along two transects in Mt. Arayat, National Park, Pampanga, Philippines. Mycology 3: 119-126.

Dagamac NH, Stephenson S, Dela Cruz TE. 2014. The occurrence of litter Myxomycetes at different elevations in Mt. Arayat National Park, Pampanga, Philippines. Nova Hedwigia 98: 187-196.

De Padua LS, Bunyapraphatsara N, Lemmens RHMJ. 1999. Plant Resources of South-East Asia No. 12 (1): Medicinal and Poisonous Plants, Backhuys Publishers, Leiden.

de Tavera P, Hermenegildo T. 1892. Plantas Medicinales de Filipinas. B. Rico, Madrid, Spain.
Dela Cruz P, Ramos AG. 2006. Indigenous health knowledge systems in the Philippines: a literature survey. Paper presented at the 13th CONSAL Conference, Manila, Philippines, 25-30 March 2006. [Philippines].

DENR Administrative Order. 2017, Updated national list of threatened Philippine plants and their categories. DAO 2017-11. Department of Environment and Natural Resources, the Philippines. https: //server2.denr.gov.ph/uploads/rmdd/dao-2017-11.pdf,

DENR/UNEP (Department of Environment and Natural Resources/United Nations Environment Program). 1997. Philippine Biodiversity: An assessment and action plan. Bookmark Inc., Makati City, Philippines.

DENR-Region III. 2018. Central Luzon. http: //r3.denr.gov.ph/.

GBIF.org. 1999-onwards. Global Biodiversity Information Facility; GBIF Home Page. https: //www.gbif.org

Hamilton AC. 2004. Medicinal plants, conservation and livelihoods. Biodiv Conseritasv 13: 1477-1517.

Haq FU, Ahmad H, Alam M, Ahmad I, Rahatullah. 2010. Species diversity of vascular plants of Nandiar Valley Western Himalaya, Pakistan. Pak J Bot 42: 213-229

International Union for the Conservation of Nature and Natural Resources. 1994-1997. WWF and IUCN, Centers of Plant Diversity: A Guide and Strategy for their Conservation. IUCN Publications Unit, Cambridge, UK.

IUCN. 2018. The International Union for Conservation of Nature's Red List of Threatened Species. www.iucnredlist.org

JSTOR (Journal Storage). 2000-onwards. Global Plants. https://plants.jstor.org/

Kala CP, Dhyani PP, Sajwan BS. 2006. Developing the medicinal plants sector in northern India: challenges and opportunities. J Ethnobiol Ethnomed. 2: 32.

Keller R. 2004. Identification of tropical woody plants in the absence of flowers: A field guide. Birkha user, Basel, Switzerland.

Madulid DA. 2001. A Dictionary of Philippine Plant Names, 2 volumes. Makati City, Inc., Makati, Philippines.

Mukherjee PK. 2002. Alternative Systems of Medicine. In: Quality Control, Herbal Drugs: An Approach to Evaluation of Botanicals, Business Horizons, New Delhi, India.

NEDA. 2004. Medium-Term Philippine Development Plan 2004-2010. National Economic and Development Authority, Manila, Philippines.

Olowa LF, Torres MAJ, Aranico EC, Demayo CG. 2012. Medicinal plants used by the Higaonon tribe of Rogongon, Iligan City, Mindanao, Philippines. Adv Environ Biol 6: 1442-1449.

Pancho JV, Gruezo WS. 2006. Vascular flora of Mount Makiling and vicinity (Luzon, Philippines), Part 2. National Academy of Science and Technology (NAST) Philippines, Department of Science and Technology, Bicutan, Taguig City and Institute of Biological Sciences, University of the Philippines Los Baños, College, Laguna, Philippines.

Payyappallimana U. 2010. Role of Traditional Medicine in Primary Health Care: An Overview of Perspectives and Challenging. AYISSS. 14: 57-77.

Pelser PB, Barcelona JF, Nickrent DL (eds.). 2011 onwards. Co's Digital Flora of the Philippines. www.philippineplants.org

Philippine Alternative Medicine. 2011-onwards. www.stuartxchange.com/AltMedSources.html

Philippine Traditional Knowledge Digital Library on Health. 2015-2016. www.tkdlph.com

Quisumbing E. 1951. Medicinal Plants of the Philippines. Bureau of Printing, Manila, Philippines.

Rathcke BJ, Lacey E. 2003. Phenological patterns of terrestrial plants, Annu Rev Ecol Syst 16: 179-214.

Rummel DJ. 2005. Useful Plants of The Philippines. C\&E Pub., Quezon City, Philippines.

SCPW. 2012. The Treepreneur Project. 2012. Society for the conservation of Philippine Wetlands, Philippines. www.wetlands.ph/projects/treepreneurship/

Sodhi NS, Posa MRC, Lee TM, Bickford D, Koh LP, Brook BW. 2010. The state and conservation of Southeast Asian biodiversity. Biodivers Conserv 19: 317-328.

Tan JG, Sia I. 2014. The best 100 Philippine Medicinal Plants, Health Futures Foundation, Inc., Manila.

Tan ML. 1980. Philippine Medicinal Plants in Common Use: Their Phytochemistry and Pharmacology. The Bookmark, Inc., Quezon City, Philippines.

The Plant List. 2010-onwards. Version 1. www.theplantlist.org/. 
Tropicos.org. 2018. Missouri Botanical Garden. www.tropicos.org

USAID. 2014. U.S. Agency for International Development. https: //rmportal.net/library/content/biodiversity-forestry-forestry.

Vanvalkenburg JL, Bunya PN. 2002. Plant Resource of South East Asia. Medicinals Plant. PROSEA Foundation, Bogor, Indonesia.

Villanueva ELC, Buot IE, JR. 2015. Threatened plant species of Mindoro, Philippines. IAMURE 14: 168.
WHO. 2011. Geneva Legal Status of Traditional Medicine and Complementary Alternative Medicine: A Worldwide Review. World Health Organisation, Geneva.

WHO. 2018. International Classification of Diseases (ICD). World Health Organization, Geneva. www.who.int/classifications/icd/en/ 